\title{
Minimization of Waste Generation at Construction Sites
}

\author{
Muhammad Akram Akhund ${ }^{\mathrm{a}}$, Ali Raza Khoso ${ }^{\mathrm{b}}$, Ashfaque Ahmed Pathan ${ }^{\mathrm{c}}$, \\ Fida Siddiqui ${ }^{\mathrm{b}}$, Irfan Ahmed Abbasi ${ }^{\mathrm{d}}$ \\ $\mathrm{a}^{*}$ PhD Scholar, Construction Management Department, Mehran UET Jamshoro \\ ${ }^{b}$ Lecturer, Civil Engineering Department, Mehran UET Jamshoro \\ ${ }^{c}$ Associate Professor, Civil Engineering Department, Mehran UET Jamshoro \\ ${ }^{\mathrm{d}} \mathrm{PhD}$ Scholar, Ocean University of China \\ Corresponding author’s mail. akhund42@gmail.com
}

\begin{abstract}
Waste has been recognized as a major problem in the construction industry and its effects on working efficiency as well on general economy of country. Waste generation results from numerous factors at different stages of construction projects. The main objective of this paper is to identify the most significant causes of waste in construction projects of Sindh. This study is based on questionnaire survey investigation. Total seventy-three (73) respondents having construction site experience, participated during data collection. The gathered data was assessed through statistical method with help of Average indexing (A.I) technique. Findings of analyzed questionnaires present that, unsuitable methods of material storage, worker's mistakes, poor management system at site, effect of sub surface ground conditions, excessive use of construction material, inexperienced constructor hire for construction project work, poor site layout, poor coordination among the construction stakeholders, improper planning schedule of project by the constructor and problem between main constructor and sub-constructor are major construction waste issues in Sindh region.
\end{abstract}

Keyword-Construction Projects, Waste Generation, WasteMinimization.

\section{INTRODUCTION}

The construction industry plays a fundamental part in meeting the necessities of society and improving the quality of life [1]. Construction projects are gettingprovocative in the near future, including work of remarkable scope and specialized complexity. These projects have been separated into four primary classes i.e. buildings development class, heavy engineering construction work class, residential construction class and industrial construction class. Each class has paramount importance for the developed environment in future [2]. Since last three decades, many construction projects have come across same problems. For example, poor productivity, inexperienced hired staff, accidents at site, inferior working conditions and poor quality of work. These issues have been identified as main components that effect construction's project performance[3]. There are various causes of construction wastage in construction projects. According to a research, construction projects generated waste from start until the completion of construction work.A research study presents his findings that, thirty three (33\%) of on-site waste occurs only due to the architects [4]. Some researchers such as [5-7] highlighted that construction waste commonly generated during the construction stage.

In 2005, a total of approximately 90 million tons of construction and demolition waste (C\&DW) were produced. Out of which 28 million tons were sent for landfilling purpose in United Kingdom (UK). Similarly, in Australia (during 2006-2007), 07 million tons of C\&DW were disposed at landfills and approximately 3 million tons of total were from construction materials[8]. A study presents findings that, construction waste has become a big issue for social and environmental departments in Hong Kong due to shortages of landfills [08].According to a research, design error, lack of design information, complicated designs and drawings, poor coordination among parties during construction stage, wrong material storage, poor material handling, material damage during transportation, poor workmanship, poor monitoring and controlling system and unforeseen ground condition are main factors of construction waste in state of South America Lime, Peru [6]. However, this paper focuses on identification of major waste generation causes in construction industry projects of Sindh region.

\section{WASTE GENERATION CAUSES IN CONSTRUCTION PROJECTS}

Waste is defined as "any inefficiency that results in improper use of equipment, materials \& labor etc., or loss of capital by ordering larger quantities than those considered necessary in the production of a building [10]. Waste is usually caused by a combination of events,and not by an isolated factor. Waste includes both the incidence of material losses and the execution of unnecessary work, which generates additional costs but does not add value to the product. Therefore, waste can be defined as, any loss produced by activities that generate direct or indirect costs but do not add value to the product from the point of view of the client $[7,11]$.

Construction waste decreases the effectiveness, profitability, efficiency and value of construction activities. Hence, it is very imperative to identify the causes of construction waste generation.A studyinvestigated the 
issues of construction waste generation, as per the research findings, poor site supervision and management, poor planning and scheduling, inexperience hired staff, errors and mistakes occurs in designs and mistakes during construction are essential factors responsible for construction site waste.Recently, in Iran a research discoveredthe major causes of construction waste occurrence at sites i.e.lack of skills, lack of knowledge of demolition, use of old methods of construction, low quality material, inappropriate method for shipment and frequent demolition [13]. Errors in design, frequent changes in design, inexperience workers, weather effect and failure of equipment at site during construction works are most essential causes of construction waste in under developed regions of world [14]. The literature is rich in different regions globally related to construction waste, however this research study based on identifying the waste generation factors in Sindh region, which fulfill the major gap in literature.

\section{DATA COLLECTION AND ANALYSIS}

A quantitative method was used for conducting questionnaires with experienced personnel involved in construction projects. On the basis of identified factors, the targeted respondents were asked about level of significance of these factors in relation to Sindh region's construction projects.Level of significance of these factors weremeasured on an ordinal scale.A five point Likert's scale was adopted for collection of data through questionnaire survey.Where " 1 " describes to not significant and " 5 " describesto extremely significant. Analysis of factors was done with Statistical Software Package (SPSS) version 20. After analyzing the gathered data, the rank of each factor was decided on the basis of average index values. Literature reveals that average index method formula has been used in data analysis [15].

$$
\text { Average Index }=\frac{\sum(1 \mathrm{X} 1+2 \mathrm{X} 2+3 \mathrm{X} 3+4 \mathrm{X} 4+5 \mathrm{X} 5)}{\sum(X 1+X 2+X 3+X 4+X 5)}
$$

\section{RESULTS AND DISCUSSION}

The data was collected through a questionnaire survey. Construction practitioners such as clients, consultants and constructors of Sindh region were the targeted respondents for this study. A total of 110 questionnaires were distributed among targeted respondents. Seventy three (73) questionnaires were received and valid for data assessment purpose. Figure 1 and 2 present the response of received questionnaires and experience level of respondents respectively.The collected data was analyzed to find out the most significance waste generation factors in construction projects of Sindh region. Average index (A.I) value of every significance factor of construction waste with its rank is shown in Table 1.

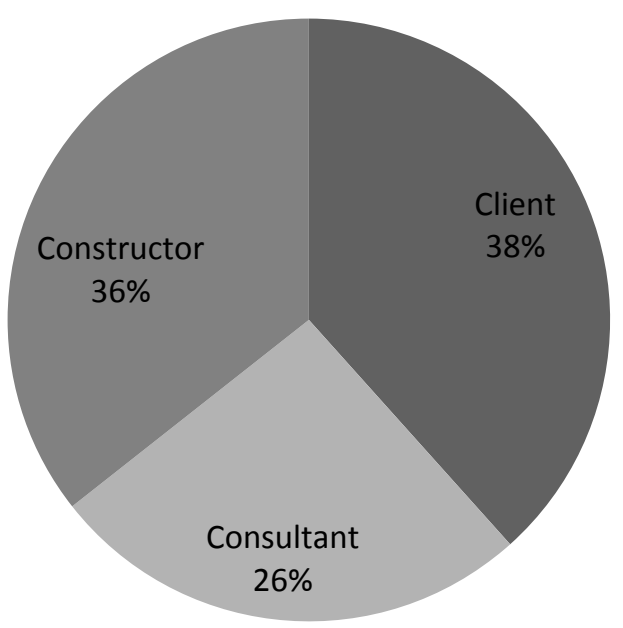

Fig.1. Response of questionnaires received from respondents 


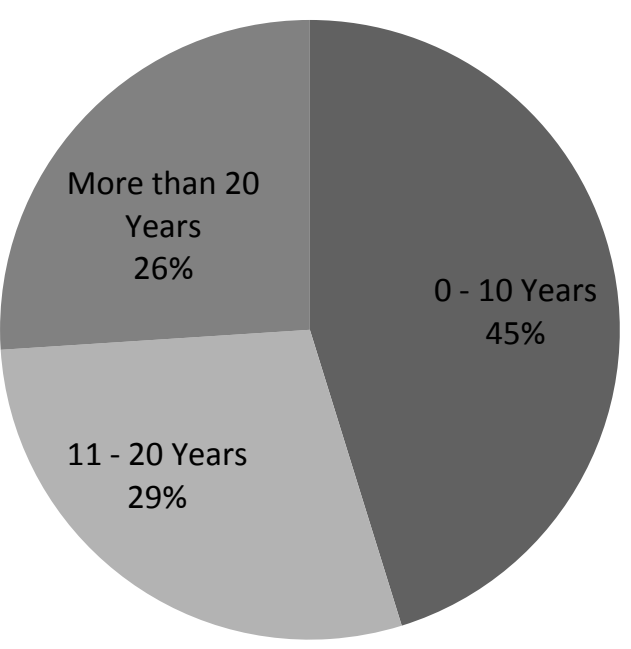

Fig. 2. Experience level of respondents

TABLE 1. Ranking of Significance Factors of Construction Waste Generation

\begin{tabular}{|c|l|c|c|}
\hline Sr. No. & \multicolumn{1}{|c|}{ Factors of construction Waste Generation } & A.I & Rank \\
\hline 1 & Unsuitable methods of material storage & 4.44 & 1 \\
\hline 2 & Worker's mistakes & 4.17 & 2 \\
\hline 3 & Poor management system at site & 4.14 & 3 \\
\hline 4 & Effect of sub surface ground conditions & 4.10 & 4 \\
\hline 5 & Excessive use of construction material & 4.10 & 4 \\
\hline 6 & Poor site layout & 3.86 & 5 \\
\hline 7 & Poor coordination among the construction stakeholders & 3.83 & 6 \\
\hline 8 & Improper planning schedule of project by the constructor & 3.77 & 7 \\
\hline 9 & Problem between main constructor and sub-constructor & 3.77 & 7 \\
\hline 10 & Poor weather conditions & 3.66 & 8 \\
\hline 11 & Poor storage of construction material & 3.63 & 9 \\
\hline 12 & Delay in arriving of workers and material at site & 3.60 & 10 \\
\hline 13 & Damage during transportation & 3.57 & 11 \\
\hline 14 & Materials damage at site & 3.57 & 11 \\
\hline 15 & Inadequate staking at site & 3.57 & 11 \\
\hline 16 & Poor behavior with project stakeholders & 3.51 & 12 \\
\hline 17 & Wrong handling of materials & 3.51 & 12 \\
\hline 18 & Unskilled and inexperience labor & 3.49 & 13 \\
\hline 19 & Bribery and Theft & 3.47 & 14 \\
\hline 20 & Expensive material imported from foreign & 3.44 & 15 \\
\hline 21 & Inexperienced sub-constructor & 3.42 & 16 \\
\hline 22 & Poor information path & 3.40 & 17 \\
\hline 23 & Political issues & 3.31 & 18 \\
\hline 24 & Manufacturing defects in materials & 19 \\
\hline 25 & Poor workmanship & 20 \\
\hline
\end{tabular}

The result of study indicates that, unsuitable methods of material storage (UMMS) is the most significance cause of waste generation in construction project of Sindh with highest average index (A.I) value of 4.44. Worker's mistakes (WM) during execution is ranked as the second most severe cause of construction waste generation. While other most significance construction waste generation factors include; poor management system at site (PMSS), effect of sub surface ground conditions (ESSGC), excessive use of construction material 
(EUCM), poor site layout (PSL), poor coordination among the construction stakeholders (PCAS), improper planning schedule of project by the constructor (IPSPC), problem between main constructor and sub-constructor (PBC\&SC) and poor weather conditions (PWC). Further, the average index value of most significant construction waste factors isrepresented in figure 03.

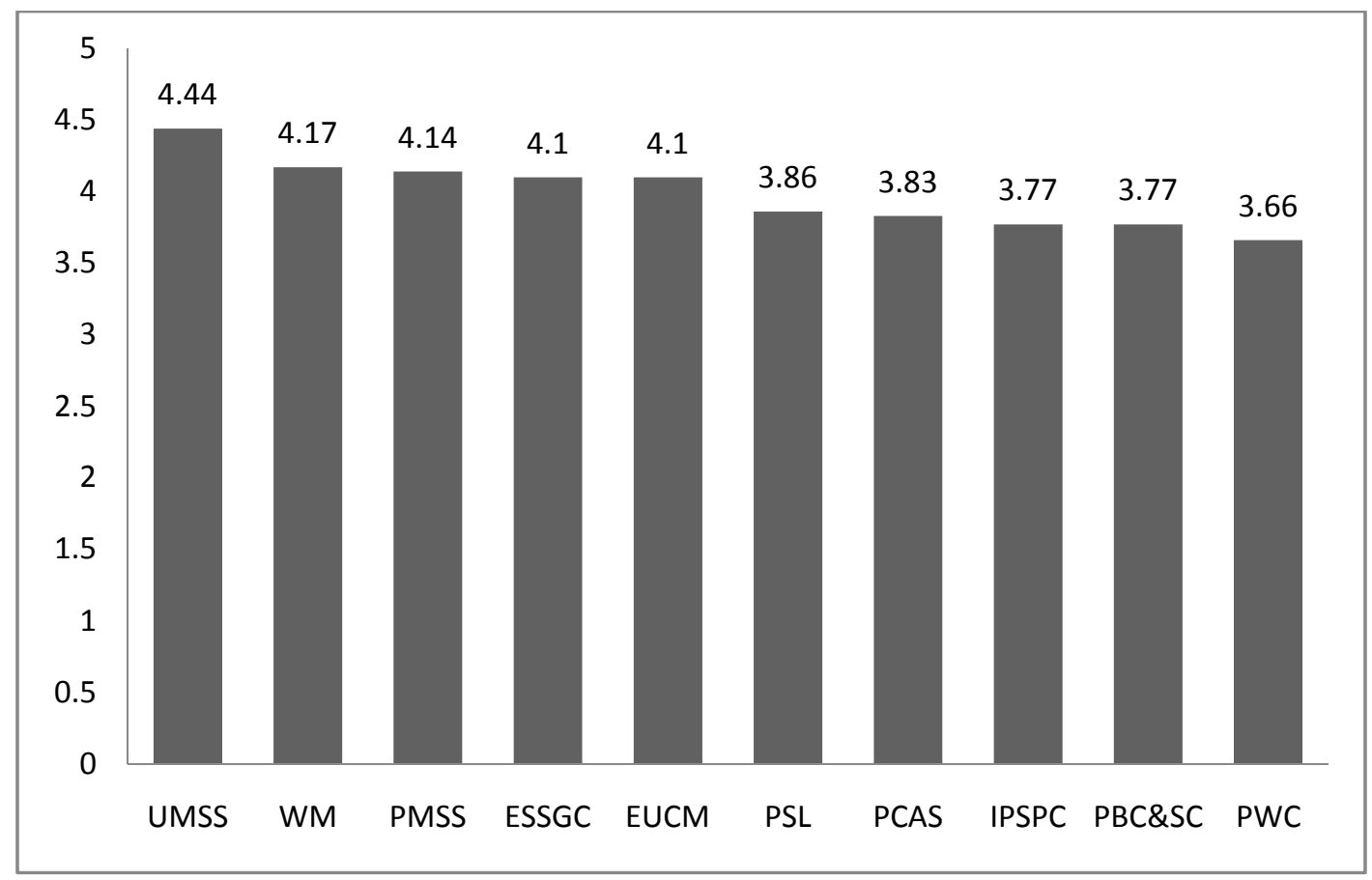

Fig.3. Most significant construction waste factors

\section{CONCLUSION AND SUGGESTION}

The main target of this research work is to identify the construction waste factors in construction projects of Sindh. The significance level of these causative factors wasdetermined througha questionnaire survey. The respondents were targeted from Sindh region with rich site experience of construction. Average index technique was used to examine the level of importance of causative factor and then to decide their rank. The results of the study identified the top most significance factors of construction waste in Sindh region projects. Unsuitable methods of material storage (UMMS), worker's mistakes (WM), poor management system at site (PMSS), effect of sub surface ground conditions (ESSGC) and excessive use of construction material (EUCM) are major causes of construction waste generation. Therefore, the research concludes that, there is seriousnecessityfor minimizing the construction waste in Sindh region projects by reducing the identified major causes of this research work. On the basis of results, the authors provide following suggestions for construction practitioners to minimize waste generation in construction projects of Sindh.

1. Design a systematic method for construction handling and storage of materials.

2. Construction personnel should arrange meetings on daily basis and develop a path for improving communication and coordination among the stakeholders.

3. A fully authorized site supervisor/inspector must be hired and available at the site for monitoring, however a senior engineer must visit the site regularly to resolve the site issues.

4. Ground condition must be known prior to executionof work on site and work should be carried out as per engineer's direction.

5. Proper quantity estimation must be done and engineer at site must ensure the material utilization as per estimation.

6. Proper site layout plans be made by the constructor, which help the construction practitioners in resolving poor site layout issues before staring any work at construction site.

7. Construction players should develop a waste management plan system to minimize the waste.

8. All stakeholders should beaware about weather conditions of construction site.

\section{ACKNOWLEDGEMENT}

The authors would like to thanks Mehran University of Engineering and Technology, Jamshoro, Sindh, Pakistan and Chairman of Civil Engineering Department for their continuous encourage and support in completing this research study. 


\section{REFERENCE}

[1] D. H. Walker, and Y.J. Shen, "Project understanding, planning, flexibility of management action and construction time performance: two

[2] Australian case studies.” Construction Management \& Economics, vol. 20 no.1, pp. 31-44, 2002.

[3] D.S. Barrie, and B.C. Paulson, Professional construction management: including CM, design-construct, and general contracting. McGraw-Hill Science/Engineering/Math. 1992.

[4] S. Alwi, K.D. Hampson, and S.A. Mohamed, "Non value-adding activities: A comparative study of Indonesian and Australian construction projects.” In 10th of the International Group of Lean Construction Conference, 6-8 August 2002, Gramado, Brazil.

[5] M. Osmani, J. Glass, and A. D. F. Price, "Architects' perspectives on construction waste reduction by design.” Waste Management, vol. 28, no.7, pp. 1147-1158, 2008.

[6] A.B. Wahab, and A.F. Lawal, "An evaluation of waste control measures in construction industry in Nigeria." African Journal of Environment, Science and Technology, vol. 5 no. 3, pp. 246-254. 2011.

[7] K. Panos, G.I. Danai, "Survey regarding control and reduction of construction waste." In PLEA2012-28th Conference, Opportunities, Limits and Needs Towards an Environmentally Responsible Architecture Lima, Perú, 7-9 Nov 2012.

[8] I.A. Rahman, N. S. Md, Akhir., A.H. Memon., and S. Nagapan., "Risk Level of Factors Contributing to Waste Generation in Construction Phase.” Conference Proceeding, InCIEC. Springer, Singapore 2014.

[9] O.O. Fadiya, P.Georgakis, and E. Chinyio, "Quantitative Analysis of the Sources of Construction Waste," Journal of Construction Engineering.,vol.2014, Oct.2014.

[10] A.T.W.Yu, C. S.Poon, A.Wong, R.Yip, and L.Jaillon, "Impact of construction waste disposal charging scheme on work practices at construction site in Hong Kong,” Waste Management, vol.33 no.1,pp.138-146, 2013.

[11] S. Nagapana, I. A. Rahman, A. Asme, and N. F. Adnan, "Study of Site's construction waste in Batu Pahat, Johar." Procedia Engineering, 53 (2013), pp.99-103.

[12] Skoyles, J.R., Waste Prevention on Site, Mitchell Publishing, London, 1987.

[13] S. Nagapana, I. A. Rahman, A. Asme, A. H. Memon, and R. M. Zin, "Identifying Causes of Construction Waste - Case of Central Region of Peninsula Malaysia.” International Journal of Integrated Engineering, vol. 4 no. 2, pp. 22-28, (2012).

[14] B. Nikmehr, M. R. Hosseini, M. Oraee, and N. Chileshe,” Major Factors Affecting Waste Generation on Construction Sites in Iran.” In EPPM2015: Proceedings of the 6th International Conference on Engineering, Project, and Production Management, Griffith School of Engineering, Griffith University, pp. 528-536.

[15] A.H. Memon, M. A. Soomro, S. N. Bhangwar,.A. H. Memon, and M. U. Memon, "Consultants' Perspective on Factors Causing Construction Waste Generation in Less Developed Regions.” International Journal of Engineering Inventions, vol. 5 no. 06, pp. 57-62.

[16] M. Akram, N. A. Memon, M. Stoian, U. Iqbal, S. H. Khahro, "Time overrun in public sector construction projects of developing countries: Case Study of Pakistan.” in Proceeding, $2^{\text {nd }}$ International Conference on Emerging Issues in Management and Economics, Oct. 2015. 